\title{
Status of Occupational Safety and Health in GCC Construction
}

Tariq Umar MSc, CEng IntPE (UK), MICE

PhD Candidate London South Bank University, UK/ Lecturer, College of Engineering, A'Sharqiyah University, Oman.

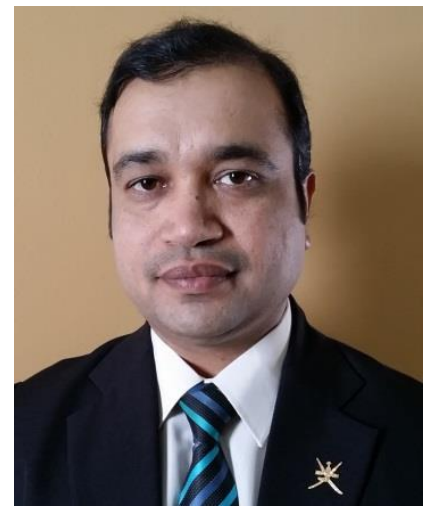

Charles Egbu PhD, FRICS, FCIOB, FAPM, FRSA, FHEA

Pro Vice Chancellor (Education and Experience), University of East London, UK.

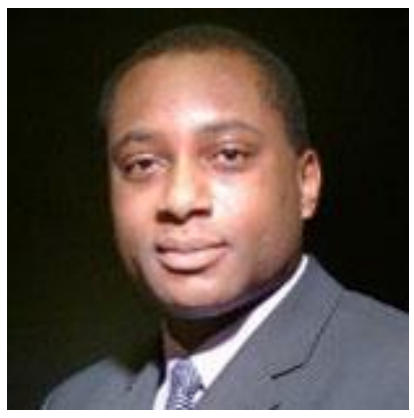

Mohamed Shaik Honnurvali M-Tech, MIET

PhD Candidate Edinburgh Napier University, UK/ Lecturer, College of Engineering, A'Sharqiyah University, Oman.

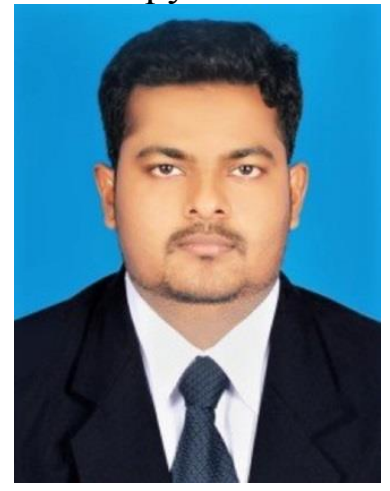


Messaoud Saidani

BEng, PhD, PgCertLT, CEng, MIStructE

Head of Research, School of Energy, Construction and Environment

Faculty of Engineering, Environment and Computing,

Coventry University, UK.

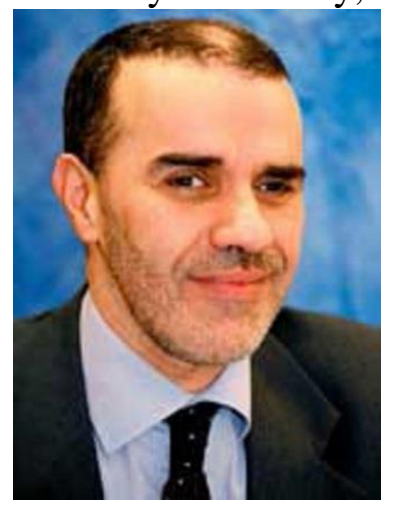

Ahmed Jalil Al-Bayati, Ph.D., P.E., CHST Assistant Professor Kimmel School of Construction Management, Western Carolina University, USA.

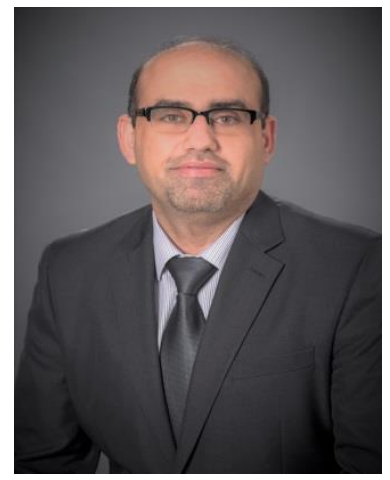




\begin{abstract}
:
The construction projects in Gulf Cooperation Council (GCC) member countries are at peak as the region is in the stage of improving its infrastructures. This paper presents the current status of the occupational safety and health in the region by providing a brief comparison with some of the advanced countries wherein improved safety performance is guaranteed and maintained. The comparison of the available data shows, that in general, GCC countries display a poor occupational safety and health performance. The paper suggests the key areas for research which could help the GCC construction industry to improve its performance. These areas include the awareness and importance of safety, cost of accidents, environmental and climatic factors which affect the workers, occupational safety and health regulations and its implementation, workers' wellbeing, safety culture and safety climate.
\end{abstract}

\title{
Keywords: Safety \& hazards, Management, Health \& safety, Project management, Knowledge management.
}

\section{Construction Safety and Health in GCC Countries:}

Although, it is a universal fact that the construction industry is not accident-free anywhere around world, however the situation in the GCC countries (Saudi Arabia, Oman, United Arab Emirates, Qatar, Kuwait and Bahrain) is more alarming. There is a lack of accurate reliable data related to the number of accidents and fatalities in these countries (Al-Bayati et al. 2017). The reports published by the media or international independent organizations are the only source for such data to rely upon. The deaths of construction workers in the construction of stadiums for the football world cup 2022 have attracted the attention of media and international organizations. Some of these reports show the number of construction workers that died in the project has already reached 1,200 . Several estimates predicting the number of deaths will reach to 4,000 by the end of 2022 when the project will be completed (ITUC, 2014; Ganji, 2016; SM, 2018). The Human Rights Watch Report indicates that the total workforce in Qatar is approximately two million. 95\% of this workforce are being expatriates and approximately, 800,000 $(=40 \%)$ are employed by the construction sector (HRW, 2018). The report further shows that in 2012 only, a total of 520 workers from India, Bangladesh and Nepal died due to different work-related accidents and conditions in Qatar. 
Similarly, Umar and Wamuziri (2016-a) noted that, officially, there are no statistics in Oman $(\mathrm{OM})$ as to how many construction workers were injured at work. However, data from ten reputable construction organizations show that in 2014, more than 3,500 construction workers received medical treatment due to work-related injuries. For various reasons including reputation, company owners hesitate to publicize such information.

In the United Arab Emirates, almost 70\% of construction organizations have a serious lack in understanding the importance of health and safety policies. Construction organizations classified as medium in size, have no designated Health and Safety officers. Most of the small construction organizations and some of the medium sized construction organizations do not have a written health and safety policy. Only $18 \%$ of construction organizations conduct continuous health and safety training for their workers (MEAC, 2014). The statistics related to occupational health and safety performance of construction organizations working in Dubai, shows that in 2013, $71 \%$ of the construction companies (out of 130) have no occupational health and safety training for their workers. Similarly, more than $70 \%$ of the construction workers believe that the training they received was outdated (SM, 2018).

The statistics published by the General Organization for Social Insurance (GOSI) of Saudi Arabia (SA) indicated that in the third quarter of 2018, occupational injuries in construction were $47 \%$ of the total occupational injuries in SA as shown in figure 1 (GOSI, 2018). This graph clearly shows that the construction industry in SA is the most hazardous sector which accumulates almost half of the injuries that took place in the third quarter of 2018. If the number of injuries is estimated at the same rate as of third quarter in 2018, then total number of injuries in a year will reach around 14500 . The statistics further reveal that in the same period, falling from a height was the most frequent cause of injuries followed by struck and collision, then rubbed and abrasion (figure 2). The GOSI statistics further indicates that the number of deaths in the third quarter of 2018 from the total injuries was 16. This can be translated into the number of deaths per year which would roughly be equal to 64 . This number, however, appears not to be reliable simply because of the overall health and safety situation in the whole region. For instance, the project of constructing football world cup stadium in Qatar resulted in 1200 death from 2010 to 2017 , roughly 171 deaths per year. 


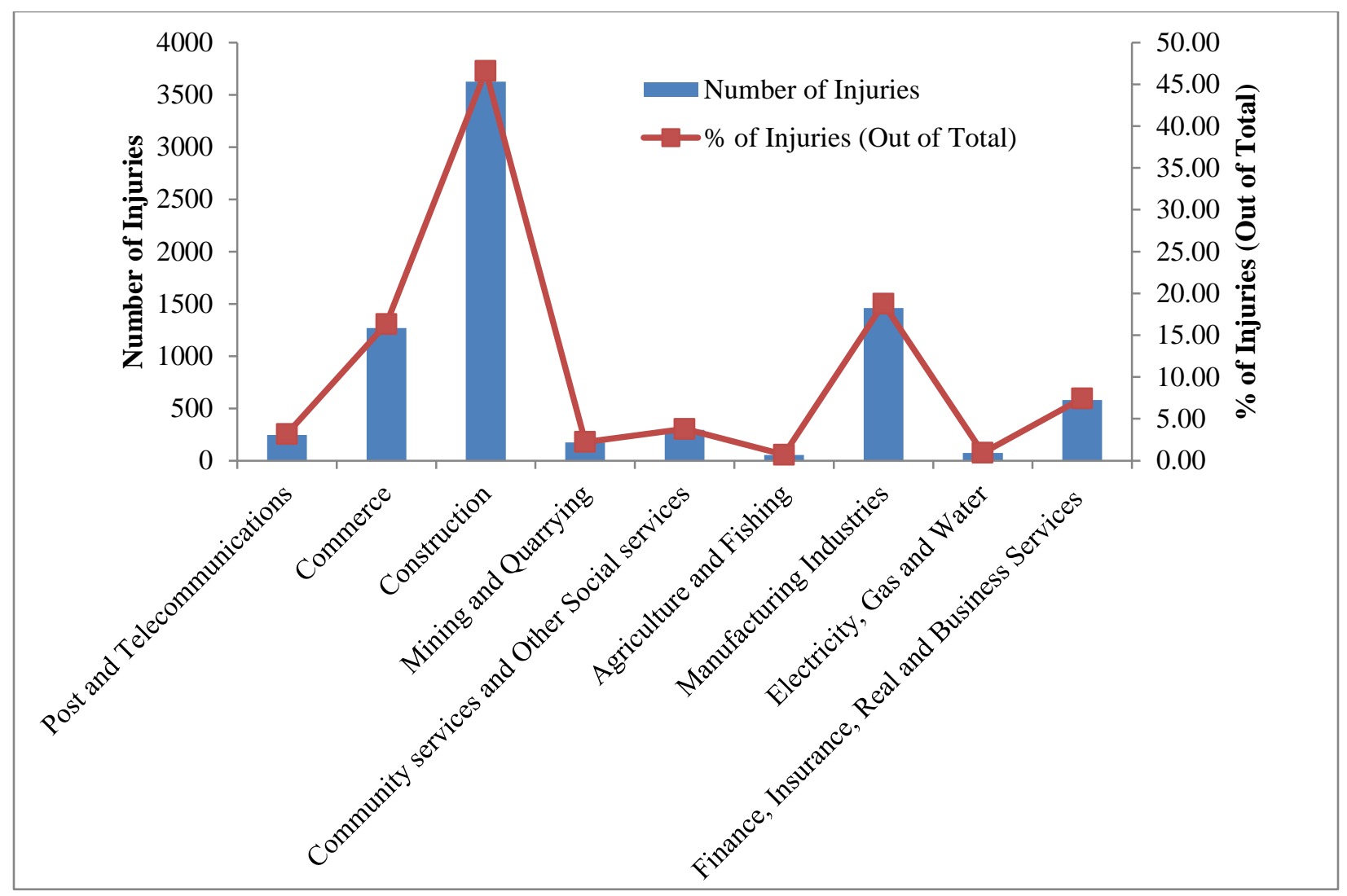

Figure 1: Number and Percentage of Injuries in Different Sectors in SA $-3^{\text {rd }}$ Quarter 2018 (GOSI, 2018). 


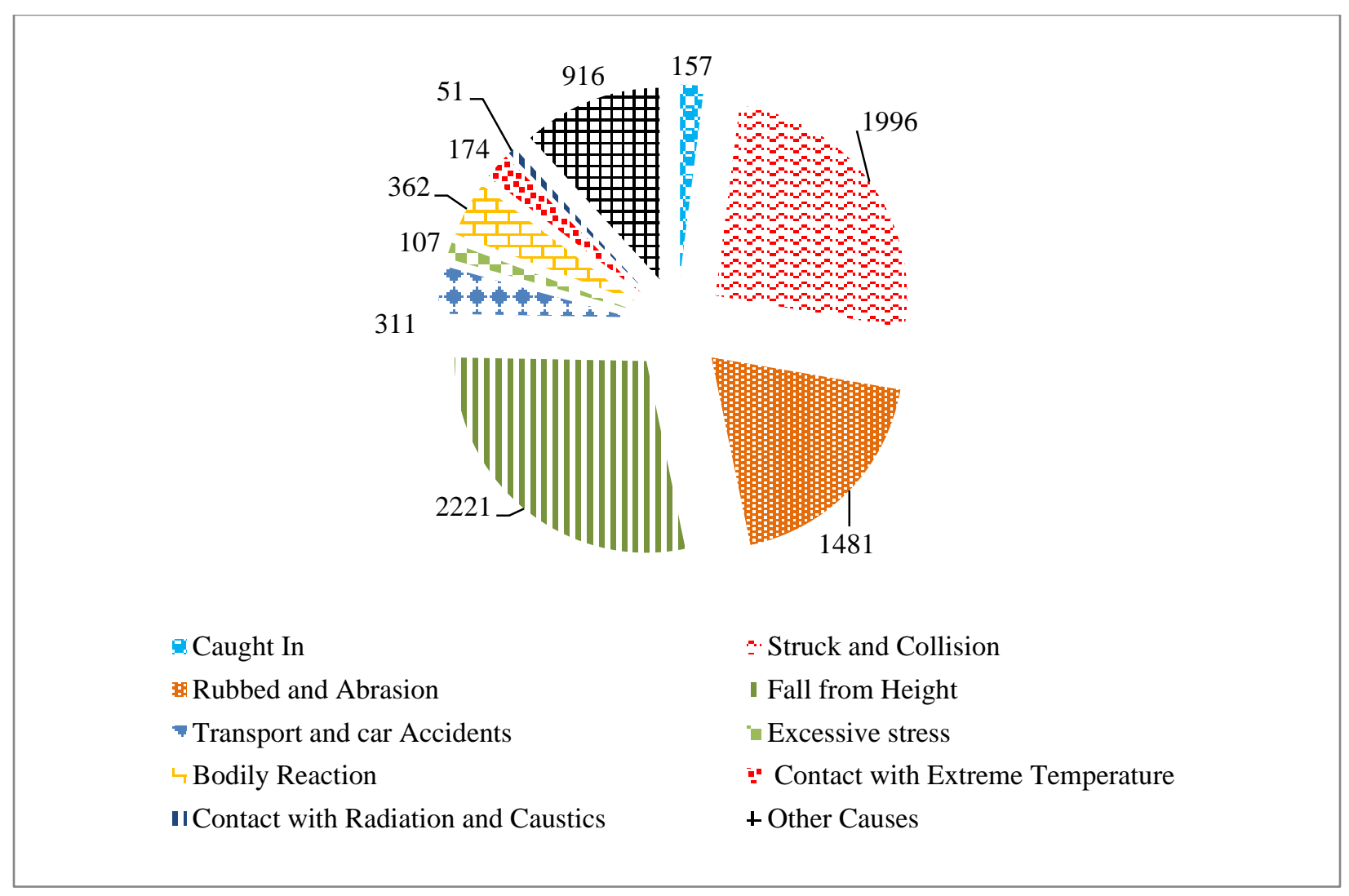

Figure 2: Different Causes of Injuries in SA - $3^{\text {rd }}$ Quarter 2018 (GOSI, 2018).

Many researchers have concluded that construction in Kuwait is found as the most hazardous industry (Kartam and Bouz, 1998; Al-Tabtabai, 2002; Al-Kandary and Al-Waheeb, 2015). Construction accidents in Kuwait were accounted for $34 \%$ - $48 \%$ for all injuries involving disabilities during 1994 to 1996. Similarly, during the same period, the accidents in construction industry in Kuwait were accounted for deaths of $42 \%$ - $62 \%$ resulting from all injuries (AlKandary and Al-Waheeb, 2015).

\section{Improving Safety Performance:}

As discussed in the above sections, workers' deaths and injuries in construction are alarming in the GCC countries. Apparently, it could be alarming in other parts of the world as well due to the nature of the industry. If so, this appears to be a global issue in which a number of factors are involved. For instance, what causes an accident or an injury in construction? If the top management of the construction organizations knows this, they will be able to develop strategies to avoid such causes or factors in their future projects (Umar et al., 2017; Umar and Egbu, 2018- 
a). Accidents in a construction project may not happen on a daily basis, and apparently, management of construction organizations remains reluctant to spend on such issues that do not appear that frequently. The main component which management may be ignoring is that although the accidents may not be occurring on regular basis in their projects, however whenever an accident happens, the cost of the accident may be overwhelming and could be greater than the cost of prevention of accidents (Umar, 2017-a; Umar, 2017-b). Thus, it is important to know what is the cost of accidents and cost of prevention of accidents in construction. Similarly, the existence of the occupational health and safety regulations and its implementation in a country play a signification role in the reduction of occupational accidents (Umar et al. 2018; Umar, 2018). For instance, in the United States, worker-deaths before the establishment of the Occupational Safety and health Administration authority in 1970 were 38 per day, which then fell to 14 per day in 2016 (OSHA, 2018). Similarly, the Construction, Design and Management $(C D M)$ regulations which were first enforced in the United Kingdom in 1995, were reviewed and amended periodically. The current CDM regulations are the third version of the actual regulations that became effective in 2015 (CDM, 2015). It is clear that the review of the current occupational health and safety regulations on a periodic basis helps organizations to monitor the effectiveness of their regulations and make necessary changes when required. The benchmarking of a country regulations with another country which display an improved safety performance can help the decision maker the proposed the necessary amendments to the existing regulations.

One of the most important factors which contribute to the performance of workers both in terms of safety and productivity is the workers' wellbeing. Specially, when it comes to GCC countries, the hot and humid environment could significantly affect the workers' performance. There have been many studies in different parts of the world in which it is concluded that the workers' performance is directly linked with the environmental condition such as humidity and temperature (Xiang et al., 2014; Yi and Chan, 2017; Umar and Egbu, 2018-b). The researchers have also established that the human response process is highly affected by their physical health (Beevers and MacGregor, 1999; Yi and Chan, 2016; Umar et al., 2019). There is, however, no comprehensive study in this area in any GCC country which considers these factors, despite the fact that all GCC countries are well known for their hot and humid climatic conditions. For instance, the Qatar Meteorology Department data shows that the mean air temperature in Doha in the month of July remains as $35.4^{\circ} \mathrm{C}$, while the mean relative humidity in the same month stands 
at $49 \%$. Similarly, the highest temperature recorded in 2010, in Doha was $50.4^{\circ} \mathrm{C}(\mathrm{MDQ}, 2018)$. The official data in OM shows that the average maximum temperature in $\mathrm{OM}$ reaches to $40^{\circ} \mathrm{C}$ in the month of June as shown in figure 3 (DGM, 2018). The maximum temperature in OM reported to be $50^{\circ} \mathrm{C}$ as by different newspapers (TOM, 2015; MD, 2016). Therefore, the effect of heat-stress on construction workers' performance in the GCC region appears to be more due to extreme environmental conditions as compared to any other part of the world. Similarly, workers' body pain supplemented by the extensive temperature may have an impact on their response-process and can affect their safety and productivity. During the construction process, workers are required to work in an awkward position for a long time. This may significantly contribute towards the body pain in specific areas.

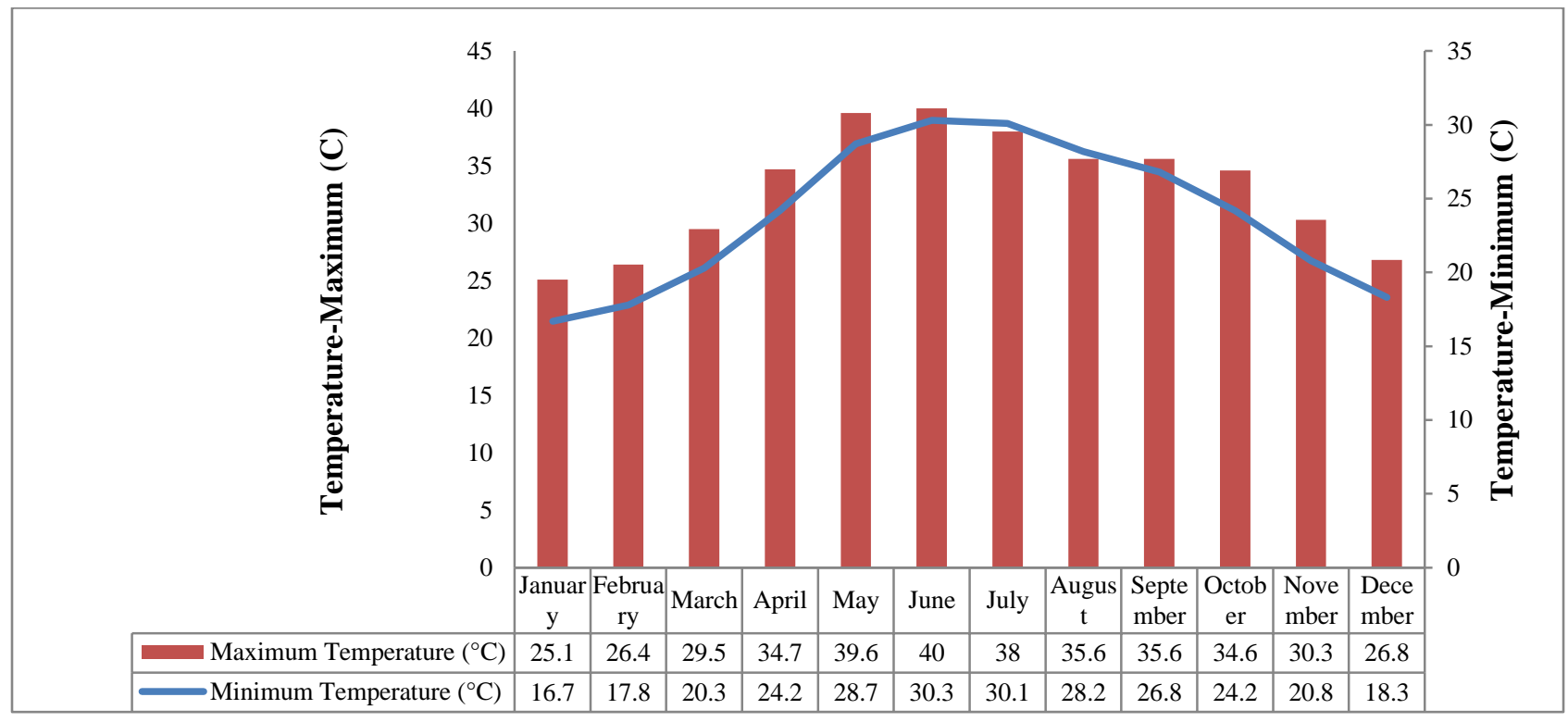

Figure 3: Average Minimum and Maximum Temperature in Oman (DGM, 2018)

While there have been several concepts and methods to improve safety performance and avoid accidents at construction site, safety culture and safety climate have attracted many researchers and practitioners worldwide due to its significant impact on the safety improvement (Kines et al., 2011, Umar and Egbu, 2018-c, Umar and Wamuziri, 2016-b). The safety culture represents the overall culture of an organization reflecting how safety is considered or treated. Overall, safety culture is contributed by the workers; however, it is highly influenced by the organization's top management. 
Safety climate is a subset of organization climate which is based on the workers' or employees' perceptions. The assessment of safety climate is considered as a barometer of safety culture. Therefore, a mature safety climate will reflect a rich safety culture (Zohar, 2002). The results of safety climate can be regarded more effective as it informs the management very clearly that in which areas; the organization needs improvement to achieve the required level of maturity (Kines et al, 2011). Worldwide, different tools have been developed for the assessment of safety climate which address industries including construction. The GCC construction, however, has its own parameters. A tool developed and used in the United Kingdom or United States may not be effective to use in the GCC countries due to a variety of factors pertaining to industry itself.

The above discussion shows that there is potential for research in the areas of occupational health and safety in construction in the GCC countries. The themes of such research may include the causes of accidents, cost of accidents, heat-stress, occupational health and safety regulations, workers' wellbeing and health, and the safety climate.

\section{Conclusion:}

Construction industry is expected to be growing rapidly in future due to increasing population and urbanization. As the construction industry grows, the risk factors associated with the industry will also grow. One of the identified risks associated with construction is the occupational fatalities and injuries. In this paper, an attempt is made to highlight this risk by exploring the occupational health and safety status in GCC construction. The statistics presented in this paper show that although construction is a leading industry in all GCC countries, the occupational health and safety performance in all these countries is not only low but quite alarming. The key elements which could be responsible for the poor safety performance are the lack of awareness of safety issues, financial implications, occupational health and safety regulations, environmental conditions and workers' wellbeing. The discussion suggests the key areas which need to be considered to improve the occupational health and safety performance in the area of construction in GCC construction industry are: the causes of accidents, cost of accidents, heat-stress, occupational safety and health regulations, workers' wellbeing and the safety climate. 


\section{Acknowledgement:}

Authors acknowledge the support in proof reading and editing provided by Dr. Uma GRajan,

English Language Lecturer from the Centre for Language and Foundation Studies, A'Sharqiyah University; OM.

\section{References:}

Al-Bayati, A. J., Abudayyeh, O., Ahmed, S. (2017). "Managing Workforce Diversity at Gulf Cooperation Council Construction Sites.” In S M Ahmad, S Azhar, N A Smith, S Campbell, L Russell and R R Watts (Editors), Proceedings of the 9th International Conference on Construction in the 21st Century (CITC-9), Dubai, United Arab Emirates. East Carolina University, Greenville, North Carolina, USA. pp. 559 - 564. ISBN: 978-09987525-1-8.

Al-Kandary, N. and Al-Waheeb, S., 2015. Patterns of accidental deaths in Kuwait: a retrospective descriptive study from 2003-2009. BMC public health, 15(1), p.302. https://doi.org/10.1186/s12889-015-1630-8.

Al-Tabtabai, H.M., 2002. Analyzing construction site accidents in Kuwait. Kuwait J. Sci. Eng, 29(2), pp.213-238.

Beevers, D.G.; MacGregor, G.A. Hypertension in Practice, 3rd ed.; CRC Press: Boca Raton, FL, USA, 1999.

CDM (Construction Design and Management). 2015. Managing health and safety in construction. Construction (Design and Management) Regulations 2015. Guidance on Regulations, Health and Safety Executive (HSE), London, UK. See: http://www.hse.gov.uk/pubns/books/1153.htm. (accessed 01/12/2018).

DGM (Directorate General of Meteorology) (2018) Average Temperature. Directorate General of Meteorology, Muscat, Oman. See: http://www.met.gov.om/opencms/export/sites/default/dgman/en/weather-chart/historicaldata/ (accessed 21/03/2018).

Ganji, S.K., 2016. Leveraging the World Cup: Mega sporting events, human rights risk, and worker welfare reform in Qatar. J. on Migration \& Hum. Sec., 4, p. 221. https://doi.org/10.1177\%2F233150241600400403.

GOSI (General Organization for Social Insurance). 2018. Open Data Library. General Organization for Social Insurance, Riyadh, Saudi Arabia. See: https://www.gosi.gov.sa/GOSIOnline/Open_Data_Library\&locale=en_US. (accessed 24/11/2018). 
HRW (Human Right Watch), 2018. Qatar: Take Urgent Action to Protect Construction Workers. Human Right Watch, New York, USA. See:

https://www.hrw.org/news/2017/09/27/qatar-take-urgent-action-protect-constructionworkers. (accessed 24/11/2018).

ITUC (International Trade Union Confederation). 2014. The Case Against Qatar, Host of the FIFA 2022 World Cup, ITUC Special Report, March 2014. International Trade Union Confederation, Brussels, Belgium. See: https://www.ituc-

csi.org/IMG/pdf/the_case_against_qatar_en_web170314.pdf. (accessed 26/11/2018).

Kartam, N.A. and Bouz, R.G., 1998. Fatalities and injuries in the Kuwaiti construction industry. Accident analysis \& prevention, 30(6), pp.805-814. https://doi.org/10.1016/S00014575(98)00033-5.

Kines, P., Lappalainen, J., Mikkelsen, K.L., Olsen, E., Pousette, A., Tharaldsen, J., Tómasson, K. and Törner, M., 2011. Nordic Safety Climate Questionnaire (NOSACQ-50): A new tool for diagnosing occupational safety climate. International Journal of Industrial Ergonomics, 41(6), pp.634-646. https://doi.org/10.1016/j.ergon.2011.08.004.

MD (Muscat Daily) (2016) 2016 Was Hottest Year on Record. Muscat Daily, 22 January. See: http://www.muscatdaily.com/Archive/Oman/2016-was-hottest-year-on-record-WMO4xdr (accessed 19/11/2017).

MDQ (Meteorology Department of Qatar), 2018. Climate Information for Doha. Meteorology Department, Doha, Qatar. See: https://qweather.gov.qa/ClimateInfo.aspx. (accessed 29/11/2018).

MEAC (Middle East Annual Conference), 2014. Managing liability for worksite accidents. Abu Dhabi Environment, Health and Safety Center, Abu Dhabi, United Arab Emirates. See: https://www.iosh.co.uk/Key-IOSH-events/Middle-East-Annual-Conference-and-AGM2014/Middle-East-Conference-presentations.aspx (accessed 05/02/2019).

OSHA (Occupational Safety and health Administration). 2018. OSHA is Making a Difference. Occupational Safety and health Administration, Washington, United States. See: https://www.osha.gov/oshstats/commonstats.html. (accessed 29/11/2018).

SM (Safety Media), 2018. Key Middle East Safety Statistics. Safety Media, Denbighshire, UK. See: https://safetymedia.co.uk/me/middle-east-safety-statistics/. (accessed 24/11/2018).

TOM (Times of Oman) (2015) Oman weather: Sultanate likely to record hottest day in the region. Time of Oman, 10 August. See: http://timesofoman.com/article/65283/Oman/Environment/Oman-weather:Sultanatelikely-to-record-hottest-day-in-the-region (accessed 19/11/2017).

Umar T and Wamuziri SC, 2016-a. A review of construction safety, challenges and opportunities - Oman perspective. In Proceedings of 5th World Construction Symposium 2016 (Sandanayake YG, Karunasena GI and Ramachandra T (eds)). University of Moratuwa, Colombo, Sri Lanka, pp. 14-22. ISSN: 2362-0919. See http://dl.lib.mrt.ac.lk/handle/123/11910 (accessed 15/01/2019). 
Umar T, Wamuziri S and Egbu C, 2017. "Causes of accidents in highway construction projects in Oman". In Proceedings of the 6th World Construction Symposium (Sandanayake YG, Ramachandra T and Gunatilake S (eds)). University of Moratuwa, Colombo, Sri Lanka, pp. 96-105. ISSN: 2362-0919. See:

https://2017.ciobwcs.com/downloads/2017_CIOBWCS_Proceedings_Book.pdf (accessed 03/02/2019).

Umar, T. and Egbu, C., 2018-a. Causes of construction accidents in Oman. Middle East Journal of Management, 5(1), pp.21-33. https://doi.org/10.1504/MEJM.2018.088725.

Umar, T. and Egbu, C., 2018-b. Heat stress, a hidden cause of accidents in construction. Proceedings of the Institution of Civil Engineers-Municipal Engineer (pp. 1-12). Thomas Telford Ltd. https://doi.org/10.1680/jmuen.18.00004.

Umar, T. and Egbu, C., 2018-c. Perceptions on safety climate: a case study in the Omani construction industry. Proceedings of the Institution of Civil Engineers-Management, Procurement and Law, 171(6), pp.251-263. https://doi.org/10.1680/jmapl.18.00001.

Umar, T. and Wamuziri, S.C., 2016-b. Using Safety Climate As A Tool For Improvement Of Safety Performance In Construction Organizations. In Proceedings of 5th World Construction Symposium 2016 (Sandanayake YG, Karunasena GI and Ramachandra T (eds)). University of Moratuwa, Colombo, Sri Lanka, pp. 545-554. ISSN: 2362-0919. See http://dl.lib.mrt.ac.lk/handle/123/11910 (accessed 15/01/2019).

Umar, T., (2018). “A Review of Occupational Safety and health Regulations in Oman”. In C R Alalouch and M B Waris (Editors), Proceedings of the $1^{\text {st }}$ National Conference on Civil \& Architectural Engineering; Department of Civil and Architectural Engineering, Sultan Qaboos University, Muscat, Oman. Pp. 79-80. ISBN: 978-99969-3-060-7.

Umar, T., 2017-a. Cost of accidents in the construction industry of Oman. Proceedings of the Institution of Civil Engineers-Municipal Engineer (Vol. 170, No. 2, pp. 68-73). Thomas Telford Ltd. https://doi.org/10.1680/jmuen.16.00032.

Umar, T., 2017-b. "Cost of Accidents in Construction in Oman". In S M Ahmad, S Azhar, N A Smith, S Campbell, L Russell and R R Watts (Editors), Proceedings of the 9th International Conference on Construction in the 21st Century (CITC-9), Dubai, United Arab Emirates. East Carolina University, Greenville, North Carolina, USA. pp. $94-103$. ISBN: 978-0-9987525-1-8. See: https://docs.wixstatic.com/ugd/0d72f4_5d48c9122cc544678d3982944868e644.pdf (accessed 02/02/2019).

Umar, T., Egbu, C., Honnurvali, M.S., Saidani, M. and Al-Mutairi, M., 2019. An assessment of health profile and body pain among construction workers. Proceedings of the Institution of Civil Engineers-Municipal Engineer (pp. 1-39). Thomas Telford Ltd. https://doi.org/10.1680/jmuen.18.00019.

Umar, T., Egbu, C., Wamuziri, S. and Honnurvali, M.S., 2018. Occupational safety and health regulations in Oman. Proceedings of the Institution of Civil Engineers-Management, Procurement and Law, 171(3), pp.93-99. https://doi.org/10.1680/jmapl.18.00007. 
Xiang, J., Bi, P., Pisaniello, D., Hansen, A. and Sullivan, T., 2014. Association between high temperature and work-related injuries in Adelaide, South Australia, 2001-2010. Occup Environ Med, 71(4), pp.246-252. http://dx.doi.org/10.1136/oemed-2013-101584.

Yi, W. and Chan, A., 2016. Health Profile of Construction Workers in Hong Kong. International journal of environmental research and public health, 13(12), p.1232. https://doi.org/10.3390/ijerph13121232.

Yi, W., and Chan, Albert, P.C. (2017). Effects of Heat Stress on Construction Labor Productivity in Hong Kong: A Case Study of Rebar Workers. International Journal of Environmental Research and Public Health. DOI: 10.3390/ijerph14091055.

Zohar, D., 2002. Modifying supervisory practices to improve subunit safety: a leadership-based intervention model. Journal of Applied Psychology 87 (1), 156-163. https://psycnet.apa.org/doi/10.1037/0021-9010.87.1.156. 